\title{
The New East's New Businesses: Heart of the Labor Market Problem and/or Part of the Solution?*
}

\author{
K. Roberts, C. Fagan, J. Tholen, L. Machacek, S. Kovatcheva, \\ B. Jung, A. Kurzynowski, T. Szumlicz, K. Foti
}

This paper is based on evidence from interviews in 1997 with 400 young (aged up to 30) self-employed people, and parallel studies of the support being offered to the self-employed by state services and non-governmental organisations (NGOS), in four East-Central European countries (Bulgaria, Hungary, Poland and Slovakia). The samples represent the New East's better-established young business people. The evidence presented in this paper explains why, in turn-ofthe-century conditions, the New East's new businesses are in danger of becoming locked into low-productivity, low wage niches. It is argued that the prospects of the new market economies in the twenty-first century depend largely on the ways in which their relationships with the European Union develop, and forms of assistance that will promote the development of the more capable SMEs into quality businesses are identified: e.g. encouraging inward investors to become mentors and customers of local enterprises; encouraging banks to become small business-user-friendly; conglomerating assistance to small enterprises within regional support centres.

Mit Hilfe der Daten, die in dieser Arbeit präsentiert werden, wird erklärt, warum die neuen Unternehmen des „,neuen Ostens" Gefahr laufen, in eine Nische der niedrigen Produktivität und des Niedriglohns zu geraten. Die Aussichten der neuen Marktwirtschaften im 21. Jahrhundert hängen von der Entwicklung der Beziehungen zur EU ab. Es werden Formen der Unterstützung vorgestellt, mit deren Hilfe fähigere kleine und mittlere Unternehmen entstehen können: z. B.: Ermutigung von Investoren, auch Mentorenrollen zu übernehmen und Kunden lokaler Unternehmen zu werden; Ermutigung der Banken, kleinen Unternehmen gegenüber offen zu sein; Konzentration der Unterstützung in regionalen Support Zentren.

\footnotetext{
* Manuscript received: 18.01.1999, revised: 25.03.1999, accepted: 08.04.1999;

The research on which this paper is based was funded by the UK Overseas Development Administration (R6665).

** Kenneth Roberts, Professor of Sociology, University of Liverpool. Colette Fagan, Lecturer in Sociology, University of Manchester. Klara Foti, Senior Research Fellow, Institute for World Economics, Hungarian Academy of Sciences. Bohdan Jung, Director of the Institute of International Studies, Warsaw School of Economics. Siyka Kovatcheva, Lecturer in Sociology, University of Plovdiv. Ladislav Machacek, Senior Fellow, Institute of Sociology, Slovak Academy of Sciences.
} 


\section{Introduction}

Small and medium-sized enterprises (SMEs) have been the heart, the main source of dynamism and growth, in the New East's new labour markets. Small private businesses were responsible for virtually all the region's new job creation in the 1990s, and by far the most vigorous employment growth was in companies created de novo (see Bilsen and Konings, 1996, Konings et al, 1995). By 1997 SMEs accounted for up to 40 percent of all employment in the former communist countries whose transitions were most advanced (Welter, 1997). This was in a context where public sector establishments had been closing or downsizing, where privatised businesses were seeking efficiency savings, and where inward investment had created new 'top of the range' jobs but these amounted to no more than a tiny proportion of all the jobs in any country.

It has become equally clear that SMEs are at the heart of the New East's most serious and persistent labour market problems. One manifestation of these problems is the high unemployment (partly open, partly concealed), especially among vulnerable groups. Unemployment is generally higher among women than among men, and it is especially high, usually over 25 percent, among young people. This unemployment is due not just to there being insufficient jobs but also to the quality of many of the jobs that have come on stream (see Roberts and Fagan, 1998). The jobs created by the New East's SMEs tend to be low paid, insecure and wholly or partly second economy. It is not merely unemployment, but also the general degradation of employment in much of the New East, which is responsible for most people in all the transition countries remaining worse-off over 10 years on than they were before any reforms commenced.

Youth unemployment remains stubbornly high despite the plethora of corrective initiatives because most of the young people concerned prefer to remain in (life stage) transition to settling in the jobs that are immediately available. And the young people have access to the financial, social and cultural resources that enable them to remain in transition. Families and the second economy often supply spending money. Families can usually be relied on to provide for basic needs - housing and food. The young unemployed's friends and families do not expect them to settle in low quality jobs. All this has been in a context where the countries themselves are believed to be in transition and, therefore, it has been possible to assume, or at least to hope, that young people's difficulties in finding work commensurate with their qualifications and aspirations will be temporary. No-one has even tried to persuade the young people or their families that an intention of the reforms was to oblige them to accept inferior jobs to those that communism offered.

Up to now the New East's SMEs have been at the heart of the countries' labour market problems but they could simultaneously become part of the solution. This will happen if the SMEs grow, help to regenerate the national economies, soak up unemployment and create competition for labour which bids up wage 
levels and other quality thresholds that need to be met if labour is to be attracted and retained. All this will happen if a sufficient number of the new enterprises evolve into quality companies, producing and marketing quality goods and services, whose high value-added enables the firms to become quality employers who can offer quality jobs.

Is this likely? We will explain that the answer will depend at least partly, and possibly largely, on the policies towards the New East that the Old West adopts and implements.

\section{Methods}

Our evidence is from interview surveys conducted during 1997 with 400 selfemployed young people in four East-Central European countries. Two of the countries, Hungary and Poland, became European Union (EU) accession states in 1998, an authoritative sign that their transitions were considered welladvanced. The trajectories of the other two countries, Bulgaria and Slovakia, remain less certain. In each of these countries the research was based in two regions, one relatively buoyant economically, and the other relatively depressed. The regions were Plovdiv and Velingrad in Bulgaria, Szabolcs and Vas in Hungary, Katowice and Suwalki in Poland, and Galanta and Trencin in Slovakia. The reason for this spread of research effort across contrasting countries and regions was, first, to ensure that whatever held in all the locations that were studied would apply across the whole of East-Central Europe, and second, to reveal how the opportunities and problems confronting the New East's new businesses, and the policies required to promote their development, might vary from place to place.

In each of the research regions parallel studies were conducted of all the support that was being offered to the young self-employed by state services and NGOS. This part of the research involved repeated site visits and interviews with key personnel in all the relevant organisations. The intention was to establish exactly what was being offered 'on the ground' as opposed to 'on paper', and, in the analysis, how a better match might be achieved between the needs of new businesses and the assistance being offered.

The entrepreneurs who were interviewed can be regarded as representing their countries' better-established young business people. They were aged up to 30 and were all in business as their main occupation. All the businesses were officially registered, had turnovers of at least USA $\$ 1000$ per year, and usually well in excess of this, and over $\$ 2$ million in some cases. Business had in fact been all the young people's main way of earning a living since they had completed their full-time education. By the time of our interviews they were all well-established in business, and expected to remain so indefinitely. None were 
just opportunistic traders. Four-fifths hoped that their children would follow their own footsteps in business.

The samples were selected by quota, from the official registers, so that all the main businesses sectors were adequately and equally represented in each region. Everywhere females comprised 30 percent of all the samples, and the respondents spanned the age range up to 30 . The interviews were basically biographical, exploring each young person's family and educational background, how and why he or she had ventured into business, the obstacles that had been encountered and how these had been addressed. Each business's current condition was explored together with the proprietor's hopes and plans for the future.

In each country all the fieldwork was conducted by local teams, operating within guidelines which ensured that the findings from all the regions would be comparable. A single data set was produced from the surveys of the young selfemployed which was made available to all the research partners who then collaborated in analysing the data, and pooled the qualitative information that had been gathered in each country.

\section{The businesses}

Most of the businesses were very basic - primitive really. This was despite the fact that by 1997 all the businesses were reasonably well-established. They had been launched with modest assets - money earned abroad, family savings and/or loans from friends. The young entrepreneurs were taking huge uncalculated risks with what, in many cases, amounted to all their personal assets, and often their families' assets also (see also Balaton, 1998). Our respondents had all survived in business (up to 1997), but in all the research regions many of the 1990s' new enterprises had failed to outlast the decade.

Some of our respondents' businesses had made spectacular progress. This was possible in the new market economies: there were no established competitors. By 1997 the businesses had annual turnovers of up to $\$ 3.5$ million though the modal turnover was just $\$ 10,000$. The young proprietors were usually taking out between $\$ 2000$ and $\$ 5000$ a year irrespective of a business's profitability. They had not adopted flamboyant, high cost lifestyles; their lives were dominated by work rather than consumption. A third were working for over 60 hours most weeks. Wherever possible profits were being ploughed back into the businesses. The young people believed that they needed to succeed quickly if they were ever to make it. As they saw their situation, the 'window of opportunity' was closing all the time. If they did not build up their own businesses they knew that other entrepreneurs would become the local market leaders.

Most of the young business people were sole proprietors. They were typically self-employed artisans and professionals. Three-fifths were working on their 
own accounts in the occupations for which they had been educated, and in which they had usually gained some prior experience elsewhere. Retailers and other traders were the group most likely to have switched from their specialities. This 'artisan model' was in fact most common in Hungary and Slovakia, the countries in which the pre-communist business cultures had been the most Germanic. However, neither Poland nor Bulgaria resembled the former Soviet countries where the generic businessman, operating with several partners, has become the dominant type (see Roberts and Tholen, 1998).

\section{Routes into business}

There had been three main routes into self-employment. The first was as an alternative to unemployment. Some respondents had reckoned that working for themselves was the only way to avoid becoming jobless, typically following layoffs or closures at state enterprises, but sometimes immediately on completing full-time education. However, very few of the young entrepreneurs had experienced prolonged unemployment: they had active dispositions.

The second route had been on the basis of experience in someone else's private ybusiness. These individuals had realised that they were capable of 'doing everything' and benefitting accordingly, and had therefore decided to set-up on their own accounts as tinsmiths, carpenters, motor mechanics, restaurant proprietors and so on.

The third route, by far the smoothest, was being, in effect, 'set up' by a family member (usually a parent or sibling) who was already in business. For example, a parent who ran a shop had helped a daughter to open another, and a father who had created a building firm had assisted a son to commence trading in building materials.

\section{Source of assistance}

Very few of the entrepreneurs were using any formal business services accountants, solicitors and suchlike. Some who had sought 'professional' help made scathing remarks about pseudo-agencies with trashy staff. Only a minority of the respondents were using banks. Business was nearly always on a cash basis. Credit was very rarely offered or expected. Business relationships were personalised, but often low trust. Families (typically with capital) and friends (typically with information, advice and contacts) had been the young business people's main source of assistance.

A third of the respondents said that they had used family connections, and a half said that they had used friends, to assist not just the start-ups, but also the development of their businesses - usually in speeding-up a registration or clearing up some other bureaucratic hassle, or to fix a deal. A third admitted to 
having made 'under the counter' payments. Having been able to use contacts, and to make unofficial payments, was related to business success (indicated by the size of turnover and profits, how well a business was equipped, its stability, and the proprietor's long-term commitment). The other predictors of business success were: being male, and therefore having access to generally masculine (though not necessarily macho) business networks, and being able to concentrate on business full-time (see also Aidis, 1997); being well-educated; and using banks.

Contacts were important in business, but not as absolutely crucial in EastCentral Europe as they have become in some former Soviet countries (see Backman, 1998). Our respondents' business chances had depended most of all on their ability to satisfy customers rather than 'protections and connections'. Bribery was not accepted as a normal business practice. None of our respondents could be described as mafiosi. According to our evidence, East-Central Europe on the one hand, and Russia on the other, have rapidly become very different types of post-communist market economies (see Eberwein and Tholen, 1997; Hanson, 1997; McMylor et al, 1998; Roberts and Tholen, 1998; Varese, 1994).

Only a minority of the young business people belonged to business associations. This was most common in Hungary and Slovakia where membership of Chambers of Commerce was becoming compulsory for the self-employed. The attitudes of these Chambers' young members were interesting. They regarded the Chambers as vestiges of communism rather than their own representatives. Few trusted any big institutions. While acknowledging that families and friends had often provided valuable assistance, most of the young business people felt that any business success that they had achieved was due basically to their own efforts.

\section{Job creation}

Just over a half of the businesses had employees. The numbers employed typically fluctuated depending on the volume of business. The jobs were often semi-casual - staff could be expected to work as and when required. Wage payments were often under-reported. This was not regarded as dishonest. The business people were unanimous (though not necessarily accurate) in their view that taxes on businesses were far too high. There was genuine (even if not objectively justifiable) outrage at the levels to which taxation had risen. Under communism such private enterprise as occurred (which usually involved some breach of the law) had not been subject to taxation, and all our respondents had assumed that in a market economy there would be less, not more, government. None of our respondents liked being outlaws. They would have preferred business to be 100 percent legitimate as they believed (wrongly) was the case in the West, but argued that this would become possible for them only when the 
playing field was level (when all businesses played by the rules), and that this would come about only when the state's demands were rolled back.

The businesses' methods of hiring and using labour made sense to the proprietors, but this was the source of the labour market problems about which job-seekers complained bitterly. None of our respondents were offering what could be described as quality jobs, let alone careers, but his did not prevent them complaining vociferously about the quality of the labour that they were able to obtain, especially from the state Labour Offices. They complained that staff were not dependable, committed or truly professional.

\section{In transition?}

The situation sketched above, with the New East's new SMEs earning handsome profits for a few proprietors but just decent livings for the majority, and offering poor quality jobs to their workers, is at the heart of the region's labour market problems. This could be a temporary situation. The enterprises could become part of the solution during their development into small and medium-sized quality firms, offering quality jobs to their employees. But this transition is not inevitable.

Post-communism is an unprecedented situation in numerous respects. One of these has been the creation of new populations of SMEs in late-twentieth century global market conditions. Most of the SMEs that we studied had been created de novo with only family or just personal savings and effort. These businesses were having to survive not only among equals, but also alongside mature multi-nationals, state enterprises, and substantial private companies created through 'honest robbery' privatisations (see Alanen, 1998; Nikula, 1998). Western capitalism's history was very different.

All the businesses that we studied were low-tech. The proprietors were equipping themselves with PCs and mobile phones but none were making anything so sophisticated. Few were trading beyond their local markets. They lacked the marketing skills and knowledge, as well as the capital, to become international, or even national market players. Many of the young people had grand hopes and aspirations, but hardly anyone had a detailed business development plan. As explained above, most were sole proprietors. They were not operating in partnerships within which resources could be pooled. Most were not even using banks. Even if they were the enterprises were unlikely to qualify for bank credit. Hardly any of the young entrepreneurs were in a position to attempt the quantum leap into the quality firm league. This chasm looked unbridgeable.

Large inward investing companies have tended to become 'cathedrals in the desert'. Many have preferred to create their own offshoots rather than to trust existing local businesses as suppliers and sub-contractors (Hardy, 1997; Lloyd- 
Reason et al, 1997). The firms that we studied served the public and other small enterprises, but not large, prestige companies. None had any 'blue-chip' customers. The new SMEs were constantly vulnerable if and when established supermarkets, garages, furniture chains and so on judged that the East's markets had developed sufficiently to justify their eastward movement (see also Tibor, 1997).

Instead of developing into quality businesses, the new SMEs could find themselves trapped in a lower tier of the new market economies. In this event one would expect there to be continuous churning within the sector (new businesses being created to replace firms that cease trading), alongside a gradual contraction in the total number of small companies as a result of competition from larger and more powerful competitors. There was a brief phase of explosive growth in SMEs in the early 1990s in all the new market economies since when the numbers of small businesses have stabilised or, in the most developed transition countries (in practice those closest to the EU), have begun to decline (see Welter, 1997), but with even the fitter survivors, with very few exceptions, remaining beneath the quantum gap to the league of quality firms offering quality jobs.

The situation was basically the same in all the regions and countries that we studied. The contrasts were weaker than we had expected. It is true that in the relatively buoyant regions and countries the more successful businesses had higher turn-overs and profits than their counterparts elsewhere, but the weaker regions had businesses that were thriving, while the relatively prosperous regions had enterprises that were struggling. Everywhere businesses' prospects depended most of all on their ability to beat local competitors. The crucial finding for present purposes is that even in the regions and countries whose transitions had been most sucessful (up to 1997), even the more successful new SMES were still trapped beneath the quantum gap. So the countries and regions concerned were not escaping from the New East's typical labour market problems - too many low quality jobs and, related to this, persistent high unemployment among vulnerable groups.

It is possible, indeed likely, that if all other things only remain equal, the New East's new SMEs will help to lock substantial segments of the new market economies into low wage, low productivity niches in the twenty-first century's global markets. The type of development was ruled-out early-on in the transformation of the former German Democratic Republic by the extent of which change was state-regulated, and by permitting negotiated wage rates to rise towards, though not up to, Western levels (see Lange and Pugh, 1998). However, these measures, in themselves, have not guaranteed a high wage, high productivity, high employment outcome to the transformation in East Germany. 


\section{Part of the solution?}

All four countries in our study had batteries of state measures intended to assist the start-up and development of new enterprises. And everywhere there were dozens of NGOs with relevant programmes, or at least aspirations to develop such programmes. Some of the measures were being supported under the European Union's PHARE programme. Some Western governments had independent initiatives, and likewise Western based NGOs, always operating with Eastern partners. On paper all the reseach regions appeared awash with assistance to new enterprises, but in practice, in specific places, the assistance was usually meagre, often low-profile, and was more geared to assisting startups than the development of the more capable existing SMEs.

The futures of the New East countries are not entirely in their own hands. Much will depend on the development of their relationships with the Old West. The European Union could integrate the New East as an outer layer - a set of expanding markets, and a reservoir of low cost labour and production sites. If, on the other hand, the New East countries are to become full and equal partners in an enlarged European Union, then, among other things, the East's more capable SMEs need to cross the quantum gap. Several complementary kinds of East-West collaboration, all currently under-developed, will aid this particular transition.

1) Business education needs to develop in the New East so that the region's new entrepreneurs have the marketing and organisational skills to enable their companies to grow. The barriers to the businesses' development are not all external to the enterprises (see also Organisation for Economic Cooperation and Development, 1997; Welter, 1997). There will be a place for MBAs in the East's prestige universities, and scholarships that enable some promising young people to study in the West. However, the greater need is for business modules within the secondary and higher education programmes that produce most of the East's young entrepreneurs, and part-time courses to enable individuals who have started-up in business to become more 'professional'. Most of our respondents were running businesses that corresponded with their specialities - the types of employment for which they had been prepared in education - but hardly anyone had received any formal education in business methods. Business skills had been picked-up informally, sometimes through tips from friends, but basically by just learning 'on the job'. This was proving sufficient to establish primitive enterprises, but not to plan their development into quality companies. Western educational institutions have considerable experience and expertise in business education. Western programmes need to be adapted and customised to the conditions in specific Eastern countries, but they can be a base to work from, and there will be plenty of willing Eastern partners and students given the 
popularity of business as a career option among the New East's latest generations of adults (see Roberts and Jung, 1995).

2) Inward investors could be encouraged to use existing local businesses. None of our respondents were benefitting from this type of custom. Yet small enterprises are most likely to thrive within such relationships (see Levelcki, 1994). Developing such relationships might be made a condition of the inward investors' acceptance (see Bateman, 1997; Bateman and Volz, 1997), as often happens with inward investment into the existing European Union. The inward investors' own national governments, or the EU, could encourage, and cover some of the costs of, mentoring and otherwise nurturing the New East's indigenous SMEs.

3) Banks need to become pro-active in assisting the New East's new small businesses. Most of the businesses that we studied were operating in entirely different segments of their countries' new market economies to those served by banks. It was not just that only a minority were even using banks: many of the young entrepreneurs felt that becoming dependent on banks would threaten their survival through the interest and other charges that were likely to be levied. Few of these businesses were in fact likely to meet the normal conditions for bank credit. The proprietors were probably correct in their regard of banks as irrelevant to their own problems. For their part, the countries' banks were not marketing their full range of services to the small business sector. In practice the banks had little to offer. If the New East's new banking systems are to promote the development of the small business sector they will need more user-friendly products. So an extension and expansion of existing guarantee schemes, operated by the national governments, with the EU underwriting some of the risks, will be helpful, indeed necessary, if the more capable SMEs are to be assisted across the quantum gap (see also Futo, 1997; Isakova, 1997, Organisation for Economic Co-operation and Development, 1997; Welter, 1997).

4) More business support centres are needed which conglomerate state and non-governmental organisations' programmes for small businesses (see also Organisation for Economic Co-operation and Development, 1997), and the Eastern NGOs that are offering advice and other forms of business support need assistance from Western partners with expertise and track records in these activities.

In all our research areas the proportions of business people who had been helped in any way by NGOs were negligible - around one percent everywhere. This was despite all the regions appearing to be stacked with NGOs with relevant missions. In practice most NGOs were weak and ineffective. Those with programmes up-and-running, rather than merely on paper, all had foreign support. Unfortunately, the overseas donors, and the local NGOs, were more 
likely to be purveying political, and sometimes religious, ideologies than business expertise.

State programmes were making the most impact in the Polish and Slovakia regions, where the levels of take-up appeared to be due less to the measures themselves (because similar measures were operating in Hungary and Bulgaria) than the conglomeration of the assistance in high profile business support centres in the Polish regions, and in a national small business development agency in Slovakia. However, even where these measures were making the greatest impact, they were not thrusting the local SMEs across the quality gap. In practice nearly all the state support services and NGO programmes were geared to business starts rather than the development of existing SMEs.

Our conclusion is that if SMEs are to be part of the solution to the New East's labour market problems, what is required is not just more assistance, but, in some cases, a refocusing and change of emphasis.

Existing policies have helped to create genuine market economies in most of the New East countries. They have also assisted the birth of the first generation of small enterprises. The next wave of assistance needs slightly different objectives, including the promotion of SMEs with potential into quality businesses, producing quality goods and services, and offering quality jobs to their employees. The relevant measures should not been seen as merely offering favours to businessmen and women. One of the obstacles is that, within the New East countries, the self-employed are not generally regarded as deserving cases. Attitudes ranging from suspicion to outright hostility extend into the government departments that have to be responsible for implementing most forms of assitance to businesses. This opposition needs to be dissolved or side-stepped. Developing basic enterprises into quality SMEs will indeed benefit the proprietors of the successful companies, but there will also be benefits for their employees. Indeed, the developments sketched above will be essential if the benefits of the reforms are to be spread throughout the New East's workforces rather than concentrated among new elite groups of employers and employees.

\section{References}

R Aidis (1997), 'Neisas is a woman: gender and entrepreneurship in Lithuania', paper presented to Third International Conference on SME Development Policy in Transition Economies, Wolverhampton.

I Alanen (1998), 'Why did decollectivization destroy the chance to form a broadly based middle class in rural Estonia?', paper presented to conference on The Middle Class as a Precondition for a Sustainable Society, Sofia.

J Backman (1998), 'New Russians and social change', in M Kivinen, ed, The Kalamari Union: Middle Class in East and West, Ashgate, Aldershot, 15-35. 
K Balaton (1998), 'Patterns of organisational changes in Hungary in the period of transformation', paper presented to 14th EGOS Colloquium, Maastricht.

M Bateman and C Volz (1997), 'SMEs and the development of subcontracting: the case of Azerbaijan', paper presented to Third International Conference on SME Development Policy in Transition Economies, Wolverhampton.

V Bilsen and J Konings (1996), Job Creation, Job Destruction and Growth of Newly Established Firms in Transition Economies: Survey Evidence from Bulgaria, Hungary and Romania, Working Paper 59/1996, Leuven Institute for Central and East European Studies, Catholic University of Leuven.

W Eberwein and J Tholen (1997), Market or Mafia: Russian Managers on the Difficult Road Towards an Open Society, Ashgate, Aldershot.

P Futo (1997), 'The role of credits and guarantees in financing small businesses in Hungary', paper presented to Third International Conference on SME Development Policy in Transition Economies, Wolverhampton.

P Hanson (1997), 'What sort of capitalism is developing in Russia?' Communist Economies and Economic Transformation, 9, 27-42.

J Hardy (1997), 'Cathedrals in the desert? Transnationals, corporate strategy and locality in Wroclaw', paper presented to Regional Studies Association conference, Regional Frontiers, Frankfurt-Oder.

N lsakova (1997), 'Small business and foreign aid in Ukraine', paper presented to Third International Conference on SME Development Policy in Transition Economies, Wolverhampton.

J Konings, H Lehmann and M E Schaffer (1995), Employment Growth, Job Creation and Job Destruction in Polish Industry. 1988-91, Working Paper 38/1995, Leuven Institute for Central and East European Studies, Catholic University of Leuven.

T Lange and G Pugh (1998), The Economics of German Unification, Edward Elgar, Cheltenham.

M Levelcki (1994), 'Les fleurs du mal: as Videoton was falling to pieces more and more of them came to us', Szociologiai Szemle, 2, 137-148.

L Lloyd-Reason, M Marinova and T J Webb (1997), 'Building business support in EastCentral Europe: a Bulgarian perspective - policy issues and recommendations', in Z Sevic and G Wright, eds, Transition in Central and Eastern Europe, Vol 1, YASF/Student Cultural centre, Belgrade.

P McMylor, R Mellor and N Barkhatova (1998), 'Familialism, friendship and the small firm: survival, protection and informal relations in the new Russia', paper presented at International Sociological Association Congress, Montreal.

J Nikula (1998), 'Position, skills and capitals - routes to entrepreneurial middle class in rural Estonia', paper presented to conference on The Middle Class as a Precondition for a Sustainable Society, Sofia.

Organisation for Economic Co-operation and Development (1997), Entrepreneurship and SMEs in Transition Economies, Paris.

K Roberts and C Fagan (1998), 'Youth unemployment and social exclusion in East-Central Europe', paper presented at Work, Employment and Society conference, Cambridge. 
K Roberts and B Jung (1995), Poland's First Post-Communist Generation, Avebury, Aldershot.

K Roberts and J Tholen (1998), 'Young entrepreneurs in East-Central Europe and the former Soviet Union', in T Lines, ed, Transition to What? Restarting Development After Communism, Institute of Development Studies Bulletin, 29, 3, 59-64.

A Tibor (1997), 'Are all necessary efforts made in the transition countries to help SMEs catch up?' paper presented to Third International Conference on SME Development Policy in Transition Economies, Wolverhampton.

F Varese (1994), 'Is Sicily the future of Russia? Private protection and the rise of the Russian mafia', Archives of European Sociology, 35, 224-258.

F Welter (1997), Small and Medium Enterprises in Central and Eastern Europe Trends, Barriers and Solutions, Rheinisch-Westfalisches lnstitut für Wirtschaftsforschung, Essen. 